\title{
Analisis Persentase Kelebihan Air Irigasi pada Subak DAS Ho Saat Musim Hujan
}

\section{The Analysis of Irrigation Water Excess Percentage in Subak Ho Watershed During the Rainy Season}

\author{
Dian Dwi Cahyo Pangestu, I Wayan Tika*, I.B. Putu Gunadnya \\ Program Studi Teknik Pertanian dan Biosistem, Fakultas Teknologi Pertanian, Universitas Udayana, Badung, Bali, \\ Indonesia. \\ *email: wayantika@unud.ac.id
}

\begin{abstract}
Abstrak
Berlebihnya ketersediaan air irigasi yang disebabkan oleh debit air yang melimpahpada saat musim hujan dan sifatnya tidak merata, dimana pada bagian hulu ketersediaan air cenderung berlebih dan di hilir cenderung kekurangan. Dengan adanya kondisi seperti itu maka perlu dilakukan penelitian mengenai kelebihan air irigasi pada saat musim hujan agar dapat dilakukan pengelolaan air secara proporsional pada (DAS) Ho. Penelitian dilakukan untuk mengetahui persentase kelebihan air irigasi yang ada pada setiap subak dan menentukan teknik pengelolaan air irigasi agar proporsional pada setiap bagian subak. Perolehan data primer dilakukan dengan metode wawancara, pengamatan, dan pengukuran sedangkan data sekunder diperoleh dari (BMKG) Wilayah III Denpasar. Data yang diperoleh selanjutnya dianalisis dengan CROPWAT 8.0 untuk mencari persentase kelebihan air irigasi yang terjadi pada saat musim hujan dan untuk menentukan proposi distribusi air irigasi. Hasil penelitian menunjukan persentase kelebihan air irigasi pada subak (DAS) Ho saat musim hujan rata-rata pada daerah hulu 207,31\%, tengah 417,78\%, hilir 239,05\%. Teknik pengelolaan distribusi air pada hulu, tengah, hilir saat musim hujan agar kelebihan bersifat proporsional yaitu dengan cara mengubah debit awal sesuai dengan debit rekayasa
\end{abstract}

Kata kunci: Subak, irigasi, kebutuhan air, debit tersedia, kelebihan air.

\begin{abstract}
The excess of water availability is caused by excessive water discharge during the rainy season, and it doesn't distribute evenly between upstream and downstream, where upstream water availability tends to be oversupply and downstream is deficient. With such conditions, research is needed on excess irrigation water during the rainy season in order to perform an optimal water management in Ho Watershed. Research was conducted to determine the percentage of excess irrigation water available in each subak and determine irrigation water management techniques to be proportionate to each subak section. The acquisition of primary data is done by interview, observation, and measurement methods, while secondary data is obtained from (BMKG) Region III Denpasar. The data obtained was further analyzed with CROPWAT 8.0 to find the percentage of excess irrigation water that occurs during the rainy season and to determine the distribution portion of irrigation water. The results showed the percentage of excess irrigation water in the Ho watershed during the rainy season averaged 207,31\%, middle $417,78 \%$, downstream $239,05 \%$. Water distribution management techniques in the upstream, middle, downstream during the rainy season so that the excess is proportional by changing the initial discharge in accordance with the approximation discharge.
\end{abstract}

Keyword: Subak, irrigation, water needs, available discharge, excess water.

\section{PENDAHULUAN}

Sistem irigasi subak adalah sebuah organisasi tradisional yang berdasarkan konsep Tri Hita Karana yang bersumber dari ajaran Agama Hindu. Sistem ini merupakan salah satu bentuk sistem irigasi yang mampu memenuhi kebutuhan dinamika sistem sosioteknis masyarakat setempat. Pengelolaan air irigasi subak biasanya dilakukan dengan prinsip-prinsip keadilan, keterbukaan, harmoni, dan kebersamaan melalui suatu organisasi yang fleksibel sehingga bisa sesuai dengan kepentingan masyarakat. Selain itu, output yang diinginkan adalah meningkatnya produktivitas tanaman padi. Untuk meningkatkan produktivitas tanaman padi maka anggota subak harus menjaga bangunan jaringan irigasi agar tetap berfungsi dengan baik (Windia, 2006). Irigasi bertujuan untuk mendukung usaha tani guna 
meningkatkan produksi pertanian dalam rangka ketahanan pangan nasional dan kesejahteraan masyarakat, khususnya petani yang diwujudkan melalui keberlanjutan sistem irigasi (Juhana et al., 2015).

Salah satu faktor penting yang perlu diperhatikan dalam menjaga dan pemeliharaan jaringan irigasi termasuk pada jaringan irigasi subak adalah keberadaan sumber air irigasinya, sumber air irigasi subak pada umumnya bersumber dari aliran sungai. Debit air di Daerah aliran sungai (DAS) berasal dari jumlah curah hujan yang jatuh di atasnya yang selanjutnya mengalami evapotranspirasi, infiltrasi, perkolasi, aliran permukaan, mengisi kandungan air tanah, dan aliran sungai (Dharmananta et al., 2019). Curah hujan sebagai input akan berinteraksi dengan kondisi fisik dan morfometri DAS sehingga akan menghasilkan keluaran debit yang berbeda-beda (Malahayati, 2009). Maka diperlukannya pengelolaan air yang tepat untuk usaha tani padi karena pengeloloaan air sangat penting badi produktivitas tanaman padi. Pengelolaan air yang tidak tepat akan mengakibatkan produktivitas padi akan menurun karena pada dasarnya saat masa pertumbuhan tanaman padi memiliki volume kebutuhan air yang berbeda (Kusumowarno, 2014). Agar produktivitas padi dapat efektif dalam satu satuan luas lahan, maka dibutuhkan suplai air yang cukup melalui irigasi. Tersedianya air irigasi yang cukup terkontrol merupakan input untuk meningkatkan produksi padi. Oleh karena itu, untuk menunjang ketersediaan air bagi usaha tani padi haruslah dilakukan pengelolaan air secara kontinyu baik dari segi kuantitas maupun kualitas, sehinggga menjamin padi agar tidak mengalami kekurangan air yang akan menurunkan hasil produksi.

Pada umumnya petani memberi makna terhadap masalah kekurangan, dan kecukupan air dalam kaitannya dengan kemungkinan keberhasilan pertanamannya. Karena sistem irigasi subak menganut sistem distribusi air secara proporsional, maka anggota subak harus menanggung resiko yang ada secara bersama-sama. Misalnya pada saat musim kemarau air irigasi sangat kecil dan saat musim hujan air irigasi akan berlebih, Maka dari itu untuk memperoleh penggunaan air yang optimal dan merata, maka air yang berlebihan dapat dibuang melalui saluran drainase yang tersedia pada setiap petak sawah yang dimiliki petani (Windia et al., 2005). Permasalahan yang sering dihadapi oleh petani pada (DAS) Ho saat musim hujan adalah ketersediaan air yang berlebih dan sifatnya tidak merata antara hulu, tengah, dan hilir. Pada bagian hulu ketersediaan air cenderung berlebih dan di hilir cenderung kekurangan. Dengan adanya kondisi seperti itu maka perlu dilakukan penelitian dengan tujuan untuk mengetahui persentase kelebihan air irigasi pada saat musim hujan agar dapat dilakukan pengelolaan air secara proporsional pada (DAS) Ho.

\section{METODE}

\section{Tempat dan Waktu Penelitian}

Lokasi penelitian dilakukan pada subak yang berada di DAS Ho yang berada di Kabupaten Tabanan yang melibatkan sebanyak 11 bendung di 11 subak gede dan dibagi masing-masing 5 subak di hulu, 3 subak di tengah dan 3 subak di hilir. Penelitian dilaksanakan pada bulan Pebruari - Juni 2020.

\begin{abstract}
Alat Dan Bahan
Penelitian ini menggunakan alat dan bahan seperti mistar ukur yang berfungsi untuk mengukur kedalam air pada saluran primer, data klimatologi untuk menghitung kebutuhan air irigasi dan aplikasi CROPWAT 8.0.
\end{abstract}

\section{Pelaksanaan Penelitian}

Penelitian ini menggunakan pendekatan analisis kuantitatif dan melakukan metode wawancara untuk mendapatkan data primer. Wawancara dilakukan kepada petugas bendung dari masing-masing subak untuk mengetahui luas lahan, umur padi dan nama subak. Data sekunder berupa data iklim yang diperoleh dari (BMKG) Wilayah III Denpasar.

\section{Batasan Penelitian}

Penelitian dilakukan menggunakan data debit air bulan Februari 2020 sampai Juni 2020, data curah hujan menggunakan data bulanan dari 2 stasiun ukur yang berada di Desa Jatiluwih dan Desa Meliling, dan data klimatologi lainya dari Kantor (BMKG) Wilayah III Denpasar dari tahun 2009 sampai 2019. Musim hujan diperkirakan mulai pada bulan November 2019 sampai awal April 2020 (BMKG, 2020). Waktu tanam padi pada subak bagian hulu, tengah dan hilir terdapat perbedaan waktu selama 15 hari dan waktu tanam dimulai dari subak bagian hilir dan terhakhir pada bagian hulu. 
Tabel 1. Proses budidaya tanaman padi pada subak di DAS Ho.

\begin{tabular}{lccc}
\multicolumn{1}{c}{ Bulan } & \multicolumn{3}{c}{ Periode Budidaya } \\
Pebruari (2) & Olah Tanah & Olah Tanah & I \\
Maret (1) & Olah Tanah & I & II \\
Maret (2) & I & II & III \\
April (1) & II & III & IV \\
April (2) & III & IV & V \\
Mei (1) & IV & V & VI \\
Mei (2) & V & VI & VII \\
Juni (1) & VI & VII & Panen \\
Juni (2) & VII & Panen & Panen \\
Juli (1) & Panen & Panen & Panen \\
\hline
\end{tabular}

Keterangan : Angka I-VII merupakan periode tanam padi.

\section{Pengukuran Debit Air}

Pengukuran debit air merupakan data primer yang dilakukan pada saluran primer subak, yang terdapat pada 11 bendung yang ada pada DAS Ho. Data yang diambil selama 5 bulan mulai dari bulan Februari sampai Juni.

\section{Analisis Kebutuhan Air Irigasi}

Analisis kebutuhan air irigasi dilakukan dengan bantuan aplikasi CROPWAT 8.0 tahapan dan cara kerja yang dilaksanakan adalah sebagai berikut.

1. Perhitungan evapotranspirasi potensial (ETo) menggunakan persamaan Penman dengan bantuan software CROPWAT 8.0, (Santika, 2019) dengan menggunakan data klimatologi. Data klimatologi yang digunakan merupakan data ratarata lima belas tahun terakhir dari tahun 2009 sampai dengan tahun 2019. Data iklim yang diambil bersumber dari (BMKG) Wilayah III Denpasar.

2. Perhitungan curah hujan efektif dilakukan dengan bantuan Aplikasi CROPWAT 8.0 yang menggunakan rumus Fixed Percentage 70 persen untuk perhitungan tanaman padi. Dalam perhitungan curah hujan efektif, data yang digunakan data rata-rata sepuluh tahun terakhir dari tahun 2009 sampai dengan tahun 2019 yang bersumber dari stasiun penakar hujan yang berlokasi di Desa Jatiluwih dan Desa Meliling.

3. Perhitungan evapotranpirasi tanaman (ETc) menggunakan rumus :

$\mathrm{ETc}=\mathrm{ETo} \times \mathrm{Kc}$

Keterangan :

$\mathrm{ETc}=$ Evapotranspirasi tanaman $(\mathrm{mm} / \mathrm{hari})$

Eto $=$ Evapotranspirasi potensial $(\mathrm{mm} / \mathrm{hari})$
$\mathrm{Kc}=$ Koefisien tanaman

4. Perhitungan kebutuhan air irigasi (KAI) dilakukan dengan menggunakan rumus : $\mathrm{KAI}=\mathrm{ETc}+\mathrm{P}-\mathrm{Re}$

Keterangan :

$\mathrm{KAI}=$ Kebutuhan air irigasi

$\mathrm{ETc}=$ Evapotranspirasi tanaman $(\mathrm{mm} / \mathrm{hari})$

$\mathrm{Re}=$ Curah Hujan Efektif

$\mathrm{P}=$ Perkolasi

\section{Persentase Kelebihan Air Irigasi}

Persentase kelebihan air irigasi dihitung dengan menggunakan data kebutuhan air irigasi, ketersediaan air irigasi, dan teknik pengelolaan air irigasi agar proporsional yang dilakukan pada subak bagian hulu, tengah dan hilir dengan menggunkan rumus :

$\%$ Kelebihan air $=\frac{(Q t-K A I)}{K A I} \times 100$

Keterangan :

Qt $\quad=$ Ketersediaan air

KAI $=$ Kebutuhan Air Irigasi

\section{Teknik Pengelolaan Rekayasa Ketersediaan Air Irigasi Proporsional}

1. Perhitungan rakayasa ketersediaan air irigasi proporsional dilakukan dengan menggunakan rata-rata persentase acuan proporsional yang terjadi setiap periodenya.

2. Setelah persentase acuan proporsional didapat, kemudian dilakukan perhitungan untuk mencari ketersediaan air irigasi proporsional (Qt rekayasa) dengan menggunakan rumus :

Debit rekayasa

$=\frac{(\% \text { acuan proporsional } x K A I)}{100}+K A I$

Keterangan :

KAI $=$ Kebutuhan Air Irigasi

$\% \quad=$ Acuan Proporsional

\section{Ketersediaan Air Awal Dan Ketersediaan Air Rekayasa}

Debit ketersediaan air awal didapat dengan pengukuran pada saluran primer subak yang terdapat pada 11 bendung pada (DAS) Ho, sedangkan ketersediaan air rekayasa merupakan hasil perhitungan yang didapat dari rata rata acuan proporsional setiap periode saat musim hujan. 


\section{HASIL DAN PEMBAHASAN}

\section{Kebutuhan Air Irigasi dan Debit Air Tersedia}

Analisis kebutuhan air irigasi (KAI) merupakan salah satu tahap penting yang diperlukan dalam perencanaan dan pengelolaan sistem irigasi. Kebutuhan air irigasi didefiniskan sebagai jumlah volume air yang diperlukan untuk memenuhi kebutuhan evaporasi, kehilangan air, kebutuhan air untuk tanaman dengan memperhatikan jumlah air yang diberikan oleh alam melalui hujan dan kontribusi air tanah (Priyonugroho, 2014). Musim hujan diperkirakan mulai pada bulan November 2019 sampai awal April 2020 (BMKG, 2020). Data tingkat kebutuhan air irigasi dan ingkat debit air tersedia disajikan Tabel 2 dan Tabel 3. Kebutuhan air irigasi padi sawah meliputi kebutuhan untuk evapotranspirasi, kehilangan air karena perkolasi dan rembesan, di samping itu untuk pengairan awal dibutuhkan sejumlah air untuk penjenuhan tanah.

Tabel 2.Kebutuhan air irigasi pada subak DAS Ho.

\begin{tabular}{lccc} 
& \multicolumn{3}{c}{ Kebutuhan Air Irigasi } \\
Bl/dt/ha) \\
Bulan (periode) & Hulu & Tengah & Hilir \\
\hline Pebruari (1)* & $2,56(\mathrm{o})$ & $2.56(\mathrm{o})$ & $0,31(\mathrm{v})$ \\
Maret (1)* & $2,6(\mathrm{o})$ & $0,22(\mathrm{v})$ & $0,63(\mathrm{v})$ \\
Maret (2)* & $0,22(\mathrm{v})$ & $0,22(\mathrm{v})$ & $0,70(\mathrm{v})$ \\
April (1) & $0,39(\mathrm{v})$ & $0,44(\mathrm{v})$ & $0,88(\mathrm{~g})$ \\
April (2) & $0,45(\mathrm{v})$ & $0,49(\mathrm{~g})$ & $0,85(\mathrm{~g})$ \\
Mei (1) & $0,51(\mathrm{~g})$ & $0,48(\mathrm{~g})$ & $0,84(\mathrm{~m})$ \\
Mei (2) & $0,49(\mathrm{~g})$ & $0,44(\mathrm{~m})$ & $0,78(\mathrm{~m})$ \\
Juni (1) & $0,37(\mathrm{~m})$ & $0,31(\mathrm{~m})$ & $0(\mathrm{p})$ \\
Juni (2) & $0,31(\mathrm{~m})$ & $0(\mathrm{p})$ & $0(\mathrm{p})$ \\
Juli (1) & $0(\mathrm{p})$ & $0(\mathrm{p})$ & $0(\mathrm{p})$ \\
\hline
\end{tabular}

Keterangan : Tanda $(*)$ merupakan musim hujan, huruf (o) yang berada di belakang angka menunjukan proses olah tanah, huruf (v) menunjukan periode vegetatif, huruf $(\mathrm{g})$ periode generatif dan huruf $(\mathrm{m})$ merupakan proses pemasakan gabah.
Tabel 3. Ketersediaan air irigasi pada subak DAS Ho.

\begin{tabular}{|c|c|c|c|}
\hline \multirow[t]{2}{*}{ Bulan (periode) } & \multicolumn{3}{|c|}{$\begin{array}{l}\text { Debit Tersedia } \\
(1 / \mathrm{dt} / \mathrm{ha})\end{array}$} \\
\hline & Hulu & Tengah & Hilir \\
\hline Pebruari (2)* & $2,81(\mathrm{o})$ & $2,72(\mathrm{o})$ & $1,86(\mathrm{v})$ \\
\hline Maret (1)* & $2,68(\mathrm{o})$ & $2,22(\mathrm{v})$ & $1,80(\mathrm{v})$ \\
\hline Maret (2)* & $1,56(\mathrm{v})$ & $1,32(\mathrm{v})$ & $0,92(\mathrm{v})$ \\
\hline April (1) & $0,84(\mathrm{v})$ & $0,37(\mathrm{v})$ & $0,59(\mathrm{~g})$ \\
\hline April (2) & $0,65(\mathrm{v})$ & $0,32(\mathrm{~g})$ & $0,60(\mathrm{~g})$ \\
\hline Mei (1) & $0,57(\mathrm{~g})$ & $0,30(\mathrm{~g})$ & $0,60(\mathrm{~m})$ \\
\hline Mei (2) & $0,61(\mathrm{~g})$ & $0,33(\mathrm{~m})$ & $0,74(\mathrm{~m})$ \\
\hline Juni (1) & $0,62(\mathrm{~m})$ & $0,32(\mathrm{~m})$ & $0(\mathrm{p})$ \\
\hline Juni (2) & $0,59(\mathrm{~m})$ & $0(p)$ & $0(\mathrm{p})$ \\
\hline Juli (1) & $0(\mathrm{p})$ & $0(\mathrm{p})$ & $0(p)$ \\
\hline
\end{tabular}

Keterangan : Tanda $(*)$ merupakan musim hujan, huruf(o) yang berada di belakang angka menunjukan proses olah tanah, huruf (v) menunjukan periode vegetatif, huruf $(\mathrm{g})$ periode generatif dan huruf $(\mathrm{m})$ merupakan proses pemasakan gabah.

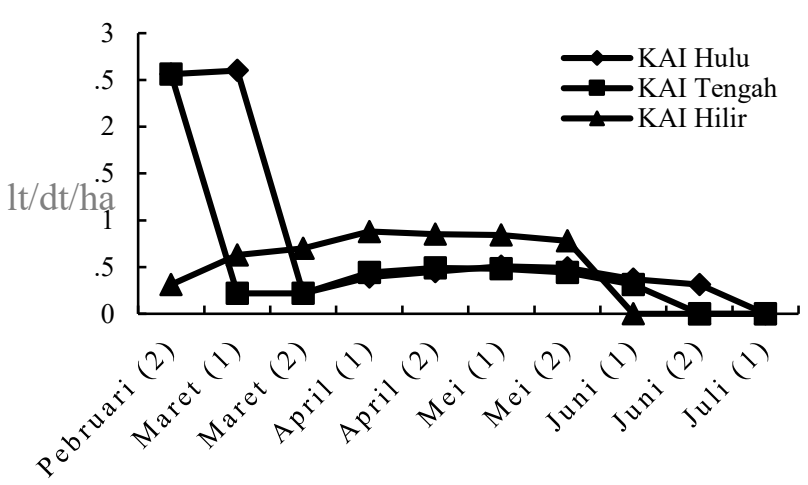

Gambar 1. Tingkat Kebutuhan Air Irigasi.

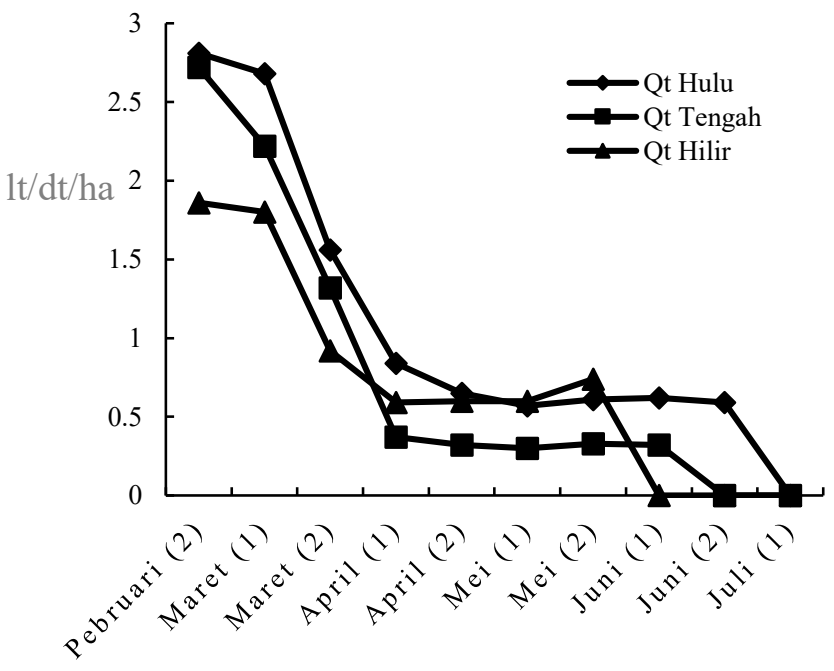

Gambar 2. Tingkat Debit Air Tersedia. 
Bedasarkan Gambar 1 grafik KAI menunjukan kebutuhan air irigasi pada bulan Februari (2) untuk subak bagian hulu dan tengah memiliki jumlah kebutuhan air irigasi yang tinggi sebesar 2,56 lt/dt/ha jika dibandingkan dengan kebutuhan air irigasi pada subak bagian hilir sebesar $0,31 \mathrm{lt} / \mathrm{dt} / \mathrm{ha}$, hal ini terjadi karena perbedaan periode budidaya tanaman padi yang terjadi pada setiap bagian subak. Subak daerah hulu dan tengah memiliki nilai kebutuhan air irigasi yang sangat tinggi pada bulan Februari (2) karena merupakan proses olah tanah, sedangkan pada subak daerah hilir bulan Februari (2) merupakan proses awal tanam. Kebutuhan air irigasi pada subak daerah tengah turun secara kuantitatif terjadi pada bulan Maret (1) yaitu menjadi 0,22 lt/dt/ha yang merupakan proses awal tanam, sedangkan pada subak daerah hulu kebutuhan air irigasi masih tinggi karena pada bulan Maret (1) merupakan proses olah tanah dengan kebutuhan air irigasi sebesar 2,6 lt/dt/ha. Pada subak daerah hulu kebutuhan air irigasi mulai turun secara kuantitatif pada bulan Maret (1) menjadi 0,22 lt/dt/ha yang merupakan proses awal tanam. Kebutuhan air irigasi pada proses olah tanah memiliki nilai kebutuhan yang lebih untuk penjenuhan tanah (Fuadi et al., 2016).

Kebutuhan air irigasi subak pada daerah hulu cenderung lebih sedikit dibandingkan dengan daerah tengah dan hilir, hal ini dikarenakan subak pada daerah hulu mempunyai curah hujan yang lebih tinggi dibandingkan dengan subak daerah tengah dan hilir. Perbedaan kebutuhan air irigasi pada setiap bagian subak dipengaruhi oleh perbedaan kebutuhan air tanaman (ETc) pada setiap bulan dan curah hujan efektif (Re) perbedaan dari setiap subak bagian. Curah hujan efektif (Re) merupakan hujan yang langsung dimanfaatkan oleh tanaman untuk memenuhi kebutuhannya selama masa pertumbuhan (Heryani et al., 2020)

Ketersediaan air irigasi untuk memenuhi kebutuhan air irigasi pada subak di DAS Ho diperoleh dari perhitungan debit air pada 11 bendung yang ada pada DAS Ho mulai dari bulan Februari 2020 sampai Juni 2020. Data debit air tersebut kemudian dikelompokan menjadi 3 bagian yaitu hulu, tengah, dan hilir. Dari 3 bagian tersebut terdapat 5 bendung pada subak bagian hulu, 3 subak bagian tengah, dan 3 subak bagian hilir. Data debit air dikelompokan kedalam debit rerata 15 hari sesuai dengan periode budidaya tanaman padi. Besaran ketersedian air irigasi dapat berasal dari curah hujan dan debit sungai yang berada disekitar lahan pertanian yang ditinjau (Fitriati et al., 2015).

Berdasarkan Gambar 2 menunjukan bahwa adanya jumlah perbedaan ketersediaan air irigasi pada subak daerah hulu, tengah, dan hilir. Grafik tersebut menunjukan bahwa debit air yang tersedia pada subak bagian hulu dan hilir memiliki nilai yang hampir sama mulai dari bulan dari bulan Maret (2) sampai Mei (1), sedangkan ketersediaan air irigasi pada subak bagian tengah memiliki nilai dibawah subak bagian hulu dan hilir. Jumlah ketersediaan air irigasi pada bulan Februari (2) memiliki perbedaan yang kuantitatif, pada subak bagian hulu memiliki ketersediaan air irigasi sebesar 2,81 1/detik/ha, subak bagian tengah sebesar $2,72 \mathrm{l} / \mathrm{detik} / \mathrm{ha}$, dan pada bagian hilir sebesar 1,86 1/detik/ha. Hal tersebut juga terjadi pada bulan Maret (2) dimana pada subak bagian hulu memiliki ketersediaan air irigasi sebesar 1,56 1/detik/ha, subak bagian tengah sebesar 1,32 1/detik/ha, dan subak bagian hilir sebesar 0,92 1/detik/ha.

Perbedaan yang terjadi pada bulan Februari (2) sampai bulan Maret (1) terjadi karena perbedaan periode budidaya tanaman padi pada setiap subak bagian. Debit air tersedia untuk budidaya tanaman padi akan lebih besar pada saat proses olah tanah, hal ini terjadi karena jumlah kebutuhan air irigasi juga menjadi lebih besar dibandingkan dengan periode awal tanam sampai panen. Debit air tersedia pada subak daerah hulu cenderung lebih besar dibandingkan subak daerah tengah dan hilir yang diakibatkan karena subak daerah hulu mendapatkan air irigasi pertama diabandingkan dengan subak bagian tengah dan hilir (Arnanda et al., 2019).

\section{Imbangan KAI Dengan Debit Air Tersedia saat Musim Hujan}

Perbandingan debit ketersediaan air dangan kebutuhan air saat musim hujan bertujuan untuk mengetahui apakah kebutuhan air pada subak DAS Ho dapat terpenuhi atau tidak. Analisis imbangan air dilakukan dengan data terakhir yaitu periode 2020 . Pada imbangan kebutuhan air irigasi dengan debit air tersedia saat musim hujan menunjukan jumlah kelebihan yang terjadi pada proses budidaya tanaman 
padi pada subak bagian hulu, tengah,dan hilir. Menurut (Yendri et al., 2019) Imbangan air pada lahan irigasi merupakan sebagai data masukan adalah hujan yang jatuh dilahan, pemberian air irigasi dan kebutuhan air tanaman sedangkan data keluaran berupa debit drainase yang dapat dimanfaatkan kembali oleh daerah irigasi hilir. Untuk mengetahui

Tabel 4. Imbangan KAI dan Qt saat musim hujan. bagaimana ketersediaan air dapat melayani kebutuhan air irigasi. Sehingga diketahui apakah mengalami kekurangan air atau kelebihan air (Suroso et al., 2007). Perbandingan kebutuhan air irigasi dengan debit air tersedia disajikan pada Tabel 4 dan gambar dibawah.

\begin{tabular}{lcccccc}
\multicolumn{1}{c}{ Bulan } & & KAI (lt/dt/ha) & & & & \\
& & & & & & \\
& & & & & & \\
& Hulu & Tengah & Hilir & Hulu $/$ ha $)$ & Hilir \\
Februari (2) & 2.56 & 2.56 & 0.31 & 2.81 & 2.72 & 1.86 \\
Maret (1) & 2.60 & 0.22 & 0.63 & 2.68 & 2.22 & 1.80 \\
Maret (2) & 0.22 & 0.22 & 0.70 & 1.56 & 1.32 & 0.92 \\
\hline Rata-rata & 1.80 & 1.00 & 0.54 & 2.41 & 2.08 & 1.52 \\
\hline
\end{tabular}

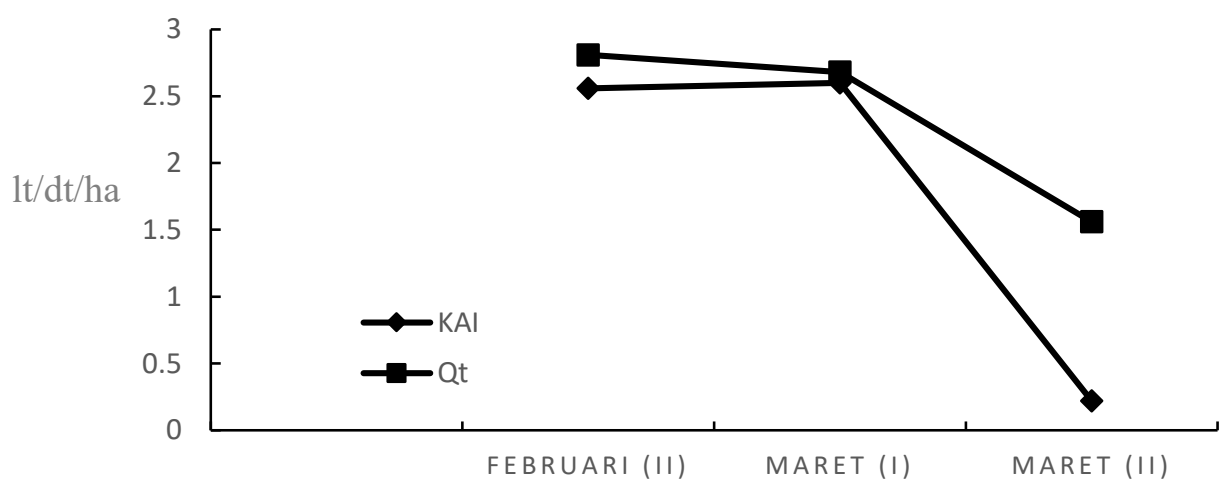

Gambar 3. Perbandingan KAI dan Qt subak bagian hulu saat musim hujan

Berdasarkan Gambar 3 menunjukan pada saat musim hujan debit air tersedia lebih besar dibandingkan dengan kebutuhan air irigasi, rata-rata debit air tersedia saat musim hujan pada subak bagian hulu sebesar 2,41 lt/dt/ha dan kebutuhan air irigasi saat musim hujan sebesar 1,80 lt/dt/ha. Dari data tersebut terdapat kelebihan air irigasi rata-rata sebesar 0,61 lt/dt/ha, hal ini menujukan terjadinya kelebihan air irigasi saat musim hujan pada subak hulu.

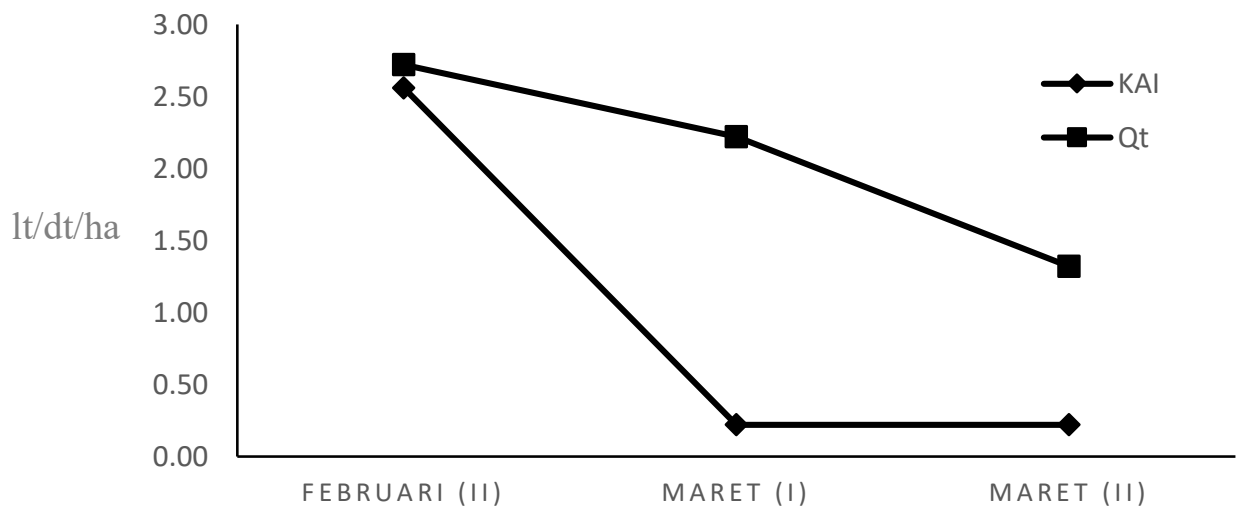


Gambar 4. Perbandingan KAI dan Qt subak bagian tengah saat musim hujan

Berdasarkan Gambar 4 menunjukan terjadinya kelebihan air irigasi saat musim pada subak bagian tengah. Kelebihan air irigasi terlihat pada bulan Februari (2) sampai bulan Maret (2), rata-rata debit air tersedia pada bulan tersebut sebesar 2,08 1t/dt/ha dengan jumlah kebutuhan air irigasi rata-rata sebesar $1,00 \mathrm{lt} / \mathrm{dt} / \mathrm{ha}$, sehingga terjadi kelebihan air irigasi sebesar $1,08 \mathrm{lt} / \mathrm{dt}$.

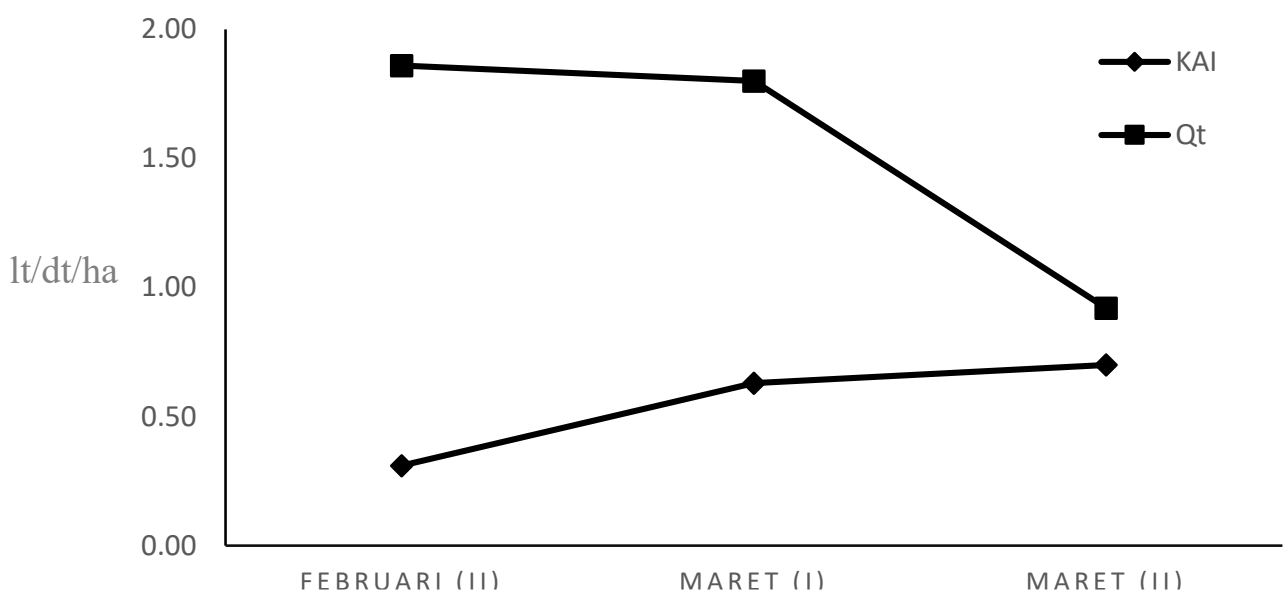

Gambar 5. Perbandingan KAI dan Qt subak bagian hilir saat musim hujan

Berdasarkan Gambar 5 menunjukan terjadinya kelebihan air irigasi saat musim hujan pada subak daerah hilir. Kelebihan air irigasi terlihat pada bulan Februari (II) sampai bulan Maret (II), rata-rata debit air tersedia pada bulan tersebut sebesar 1,52 lt/dt/ha dengan jumlah kebutuhan air irigasi rata-rata sebesar $0,54 \mathrm{lt} / \mathrm{dt} / \mathrm{ha}$, sehingga terjadi kelebihan air irigasi sebesar $0,98 \mathrm{lt} / \mathrm{dt} / \mathrm{ha}$.

\section{Persentase Kelebihan Air Irigasi pada Subak DAS Ho saat Musim Hujan}

Kelebihan air adalah sisa air dari curah hujan setelah dikurangi untuk evapotranspirasi dan pengisian lengas permukaan tanah (Fitriati et al., 2015). Berdasarkan hasil perhitungan persentase kelebihan air irigasi pada subak daerah hulu, tengah, hilir dapat dilihat pada Tabel 5.

Tabel 5. Tabel kelebihan air irigasi pada saat musim hujan.

\begin{tabular}{|c|c|c|c|c|c|c|c|c|c|c|}
\hline \multirow{2}{*}{ No } & \multirow{2}{*}{ Bulan } & \multicolumn{3}{|c|}{$\mathrm{KAI}(\mathrm{l} / \mathrm{dt} / \mathrm{ha})$} & \multicolumn{3}{|c|}{ Qt (1/dt/ha) } & \multicolumn{3}{|c|}{ (\%) kelebihan air } \\
\hline & & Hulu & Tengah & Hilir & Hulu & Tengah & Hilir & Hulu & Tengah & hilir \\
\hline 1 & Februari (2) & 2.56 & 2.56 & 0.31 & 2.81 & 2.72 & 1.86 & 9.77 & 6.25 & 500.00 \\
\hline 2 & Maret (1) & 2.60 & 0.22 & 0.63 & 2.68 & 2.22 & 1.80 & 3.08 & 909.09 & 185.71 \\
\hline 3 & Maret (2) & 0.22 & 0.22 & 0.70 & 1.56 & 1.32 & 0.92 & 609.09 & 500.00 & 31.43 \\
\hline \multicolumn{8}{|c|}{ Rata-rata (\%) } & 207.31 & 471.78 & 239.05 \\
\hline \multicolumn{8}{|c|}{ Rata-rata keseluruhan } & & 306.05 & \\
\hline
\end{tabular}

Berdasarkan Tabel 5 menunjukan persentase

kelebihan air irigasi tertinggi pada subak daerah hulu sebesar $609.09 \%$ terjadi pada bulan Maret (2) dan persentase kelebihan iri irigasi terendah pada subak daerah hulu yaitu terjadi pada bulan Maret (1) sebesar $3.08 \%$ dan rata-rata persentase kelebihan air irigasi pada subak daerah hulu sebesar $207.31 \%$, merupakan persentase kelebihan air irigasi terendah dibandingkan dengan subak daerah tengah dan hilir.

Pada subak daerah tengah persentase kelebihan air irigasi terendah terjadi pada bulan Februari (2) yaitu sebesar $6.2 \%$ dan kelebihan air irigasi tertinggi terjadi pada bulan Maret (1) yaitu sebesar $909.09 \%$ 
dan rata rata persentase kelebihan air irigasi yang didapat pada subak daerah tengah sebesar $471.78 \%$.

Persentase kelebihan air irigasi pada subak daerah hilir tertinggi terjadi pada bulan Februari (2) yaitu sebesar 500.00\% dan persentase kelebihan air irigasi terendah terjadi pada bulan Maret (2) yaitu sebesar $31.43 \%$. Rata-rata persentase kelebihan air irigasi yang didapat pada subak daerah hilir adalah sebesar $239.05 \%$.

\section{Teknik Pengelolaan Distribusi Air Proporsional pada DAS Ho}

Pengelolaan air berperan sangat penting dan merupakan salah satu faktor keberhasilan peningkatan produksi padi di lahan sawah. Produksi padi di lahan sawah akan menurun jika tanaman padi tidak mendapat suplai air yang sesuai dengan kebutuhan (Purnama et al., 2012). Penentuan proporsional pengelolaan air pada subak daerah hulu, tengah, hilir menggunakan hasil perhitungan ratarata keseluruhan persentase kelebihan air proporsional pada setiap periode. persentase kelebihan air irigasi proporsional dapat dilihat pada Tabel 6.

Tabel 6. Persentase acuan kelebihan air proporsional.

\begin{tabular}{lcccccccccccc}
\multicolumn{1}{c}{ Bulan } & \multicolumn{3}{c}{ KAI (1/dt/ha) } & & Qt (1/dt/ha) & & & \% Kelebihan air & $\begin{array}{c}\text { Acuan } \\
\text { proporsional } \\
(\%)\end{array}$ \\
& & & & & & & & & & & & \\
& Hulu & Tengah & Hilir & Hulu & Tengah & Hilir & Hulu & Tengah & Hilir & \\
\hline $\begin{array}{l}\text { Februari } \\
(2)\end{array}$ & 2.56 & 2.56 & 0.31 & 2.81 & 2.72 & 1.86 & 9.77 & 6.25 & 500.00 & 172.01 \\
Maret (1) & 2.60 & 0.22 & 0.63 & 2.68 & 2.22 & 1.80 & 3.08 & 909.09 & 185.71 & 365.96 \\
Maret (2) & 0.22 & 0.22 & 0.70 & 1.56 & 1.32 & 0.92 & 609.09 & 500.00 & 31.43 & 380.17 \\
\hline
\end{tabular}

Berdasarkan hasil perhitungan persentase kelebihan air irigasi pada subak daerah hulu, tengah, dan hilir didapatkan hasil kelebihan air irigasi proporsional dari masing masing periode. Pada bulan Pebruari (2) memiliki rata-rata kelebihan air irigasi proporsional sebesar $172,01 \%$ hal ini menunjukkan rata-rata persentase kelebihan air proporsional terendah diantara bulan Maret (1) dan Maret (2). Pada bulan Maret (1) memiliki rata-rata kelebihan air proporsional sebesar 365,96\% dan pada bulan Maret (2) persentase kelebihan air proporsional sebesar $380,17 \%$ yang merupakan persentase tertinggi. Rekayasa ketersediaan air irigasi dapat dilihat pada Tabel 7.

Tabel 7. Rekayasa ketersediaan air irigasi proporsional

\begin{tabular}{|c|c|c|c|c|c|c|c|c|c|}
\hline \multirow{2}{*}{ Bulan } & \multicolumn{3}{|c|}{$\mathrm{KAI}(\mathrm{l} / \mathrm{dt} / \mathrm{ha})$} & \multicolumn{3}{|c|}{ Qt Rekayasa (1/dt/ha) } & \multicolumn{3}{|c|}{ Kelebihan air (\%) } \\
\hline & Hulu & Tengah & Hilir & Hulu & Tengah & Hilir & Hulu & Tengah & Hilir \\
\hline Februari (2) & 2.56 & 2.56 & 0.31 & 6.96 & 6.96 & 0.84 & 172.01 & 172.01 & 172.01 \\
\hline Maret (1) & 2.60 & 0.22 & 0.63 & 12.11 & 1.03 & 2.94 & 365.96 & 365.96 & 365.96 \\
\hline Maret (2) & 0.22 & 0.22 & 0.70 & 1.06 & 1.06 & 3.36 & 380.17 & 380.17 & 380.17 \\
\hline Rata-rata & 1.79 & 1.00 & 0.55 & 6.71 & 3.01 & 2.38 & & 306.05 & \\
\hline
\end{tabular}


Untuk mencapai acuan proporsional seperti Tabel 6, perlu dilakukan rekayasa terhadap ketersediaan air irigasi. Berdasarkan Tabel 7 Qt awal pada subak derah hulu di bulan Pebruari (2) sebesar 2,81 lt/dt/ha dan Qt rekayasa sebesar 6,96 lt/dt/ha. Hal ini menunjukan Qt awal harus dinaikkan sebesar 4,15 lt/dt/ha agar pengelolaan air irigasi dapat proporsional. Pada bulan Maret (2) Qt awal sebesar 2,68 1t/dt/ha dan Qt rekayasa sebesar 12,11 lt/dt/ha. Hal ini menunjukan agar pengelolaan air irigasi dapat proporsional, maka Qt awal harus dinaikkan sebesar 9,43 lt/dt/ha. Pada bulan Maret (2) Qt awal sebesar 1,56 lt/dt/ha dan Qt rekayasa sebesar 1,06 lt/dt/ha. Berdasarkan nilai tersebut agar pengelolaan air irigasi dapat proporsional maka Qt awal pada bulan Maret (2) harus diturunkan sebesar $0,5 \mathrm{lt} / \mathrm{dt} / \mathrm{ha}$.

Pada subak daerah tengah Qt awal di bulan Pebruari (2) sebesar 2,72 1t/dt/ha dan Qt rekayasa sebesar 6,69 lt/dt/ha. Hal ini menunjukan agar pengelolaan air irigasi dapat proporsional, maka Qt awal harus dinaikkan sebesar 3,97 lt/dt/ha. Pada bulan Maret (1) Qt awal sebesar 2,22 1t/dt/ha dan Qt rekayasa sebesar $1,03 \mathrm{lt} / \mathrm{dt} / \mathrm{ha}$. Berdasarkan nilai tersebut agar pengelolaan air irigasi pada bulan Maret (1) dapat proporsional, maka Qt awal harus diturunkan sebesar 1,19 lt/dt/ha.s Pada bulan Maret (2) Qt rekayasa sebesar 1,06 lt/dt/ha dan Qt awal sebesar 1,32 lt/dt/ha. Hal ini menunjukan agar pengelolaan air irigasi pada bulan Maret (2) dapat proporsional, maka Qt awal harus diturunkan sebesar $0,26 \mathrm{lt} / \mathrm{dt} / \mathrm{ha}$.

Pada subak daerah hilir Qt awal di bulan Februari (2) sebesar 1,86 lt/dt/ha dan Qt rekayasa sebesar 0,84 lt/dt/ha. Hal ini menunjukan agar pengelolaan air irigasi pada bulan Pebruari dapat proporsional, maka Qt awal harus diturunkan sebesar 0,84 lt/dt/ha. Pada bulan Maret (1) Qt awal sebesar 1,80 lt/dt/ha dan Qt rekayasa sebesar 2,94 1t/dt/ha. Berdasarkan nilai tersebut menunjukan agar pengelolaan air irigasi pada bulan Maret (1) dapat proporsional, maka Qt awal harus dinaikkan sebesar 1,14 1t/dt/ha. Pada bulan Maret (2) Qt awal sebesar 0,92 1t/dt/ha dan Qt rekayasa sebesar 3,36 lt/dt/ha. Hal ini menunjukan menunjukan agar pengelolaan air irigasi pada bulan Maret (2) dapat proporsional, maka Qt awal harus dinaikkan sebesar 2,44 lt/dt/ha.

\section{KESIMPULAN}

Ketersediaan air irigasi pada subak DAS Ho saat musim hujan melebihi dari kebutuhan air irigasi. Persentase kelebihan air irigasi pada subak DAS Ho saat musim hujan, rata-rata pada daerah hulu 207,31\%, tengah 417,78\%, hilir 239,05\%. Teknik pengelolaan distribusi air pada hulu, tengah, hilir saat musim hujan agar kelebihan bersifat proporsional yaitu dengan cara mengubah debit awal sesuai dengan debit rekayasa yang didapat dengan menggunakan hasil rata-rata persentase acuan proporsional yang terjadi setiap periodenya saat musim hujan. Pada daerah hulu rata-rata debit awal sebesar 2,35 1/dt/ha diubah menjadi sebesar 6,71 lt/dt/ha, daerah tengah dari 2,09 1/dt/ha diubah menjadi 3,01 1/dt/ha, dan pada daerah hilir rata-rata debit awal sebesar 1,53 1/dt/ha diubah menjadi sebesar 2,38 1/dt/ha. Perubahan debit air dapat dilakukan dengan mengatur pintu saluran pemasukan.

\section{DAFTAR PUSTAKA}

Andi Juhana, E., Permana, S., \& Farida, I. 2015. Analisis Kebutuhan Air Irigasi Pada Daerah Irigasi Bangbayang Uptd Sdap Leles Dinas Sumber Daya Air dan Pertambangan Kabupaten Garut. Jurnal Konstruksi, Vol. 13 No(ISSN : 2302-7312), 1-28.

Arnanda, Y., Tika, I. W., \& Madrini, I. A. L. G. B. 2019. Analisis Rasio Prestasi Manajemen Irigasi pada Distribusi Air di Subak Kabupaten Tabanan. Jurnal BETA (Biosistem Dan Teknik Pertanian), 8(2), 290.

BMKG. 2020. Prakira Musim Hujan Tahun 2020/2021 di Indonesia.

Dharmananta, I Dewa., R. S., \& Trigunasih, N. M. 2019. Pengaruh Morfometri DAS terhadap Debit dan Sedimentasi DAS Yeh Ho. 8(1), 3242

Fitriati, U., Novitasari, N., Rusdiansyah, A., \& Rahman, A. 2015. Studi Imbangan Air Pada Daerah Irigasi Pitap. Cantilever, 4(1), 27-33.

Fuadi, N. A., Purwanto, M. Y. J., \& Tarigan, S. D. 2016. Kajian Kebutuhan Air dan Produktivitas Air Padi Sawah dengan Sistem Pemberian Air Secara SRI dan Konvensional Menggunakan Irigasi Pipa. Jurnal Irigasi, 11(1), 23.

Heryani, N., Kartiwa, B., Hamdani, A., \& Rahayu, B. 2020. Analisis Ketersediaan dan Kebutuhan Air Irigasi pada Lahan Sawah : Studi Kasus di Provinsi Sulawesi Selatan. Jurnal Tanah Dan Iklim, 41(2), 135.

Kusumowarno, S. 2014. Percepatan peningkatan produksi dan produktivitas padi di lahan rawa berkelanjutan dan lestari. In Prosiding Seminar 
Nasional "Inovasi Teknologi Pertanian Spesifik Lokasi”. Bogor.

Malahayati S.Y. 2009. Kajian Perubahan Penggunaan Lahan Terhadap Respon Hidrologi Pada DAS Cirasea Menggunakan Model MWSWAT.Surabaya.

Mediani, A., Fajar, M., Basuki, A., \& Finesa, Y. 2019. Analisis Neraca Air Dan Kebutuhan Air Tanaman Padi Kekeringan Pada Sub Das Samin. 2012, 179-187.

Priyonugroho, A. 2014. Analisis Kebutuhan Air Irigasi ( Studi Kasus Pada Daerah Irigasi Sungai Air Keban Daerah Kabupaten Empat Lawang ). Jurnal Teknik Sipil Dan Lingkungan, 2(3), 457470.

Purnama, I. L. S., Trijuni, S., Hanafi, F., Aulia, T., \& Razali, R. 2012. Analisis Neraca Air di Das Kupang dan Sengkarang. 1-79.

Santika I. K. A., Tika. I. W., Budisanjaya. I. P. G. 2019. Analisis Rasio Prestasi Manajemen Irigasi pada Budidaya Tanaman Padi di Subak Kabupaten Tabanan. Journal of Biosystem and Engineering Agriculture, 8(2), 204-210.

Suroso 1) , PS. Nugroho 2), dan P. P. 3. 2007. Evaluasi Kinerja Jaringan Irigasi Banjaran untuk Meningkatkan Efektifitas dan Efisiensi Pengelolaaan Air. 7(Di), 55-62.

Windia, W. 2006. Transformasi Sistem Irigasi Subak yang Berlandaskan Tri Hita Karana. Ojs.Unud.Ac.Id, 1-15.

Windia, Wayan, Pusposutardjo, S., Sutawan, N., Sudira, P., \& Arif, S. 2005. Sistem Irigasi Subak Dengan Landasan Tri Hita Karana (THK) Sebagai Teknologi Sepadan Dalam Pertanian Beririgasi. Social Economic of Agriculture, 5(Vol. 5, No. 3 November 2005), 1-15.

Yendri, O., Putranto, D. DA, \& Sarino, S. 2019. Analisis Besaran Komponen Imbangan Air pada Lahan Irigasi Kelingi Tugumulyo Kabupaten Musi Rawas Provinsi Sumatera Selatan. Jurnal Civronlit Unbari, 4(2), 57. 